Paul N. Hopkins • Lily L. Wu • Susan H. Stephenson

Yuanpei Xin · Harumi Katsumata • Yukiko Nobe

Toshiaki Nakajima · Tsunenori Hirayama - Mitsuru Emi

Roger R. Williams

\title{
A novel LDLR mutation, H190Y, in a Utah kindred with familial Hypercholesterolemia
}

\begin{abstract}
Heterozygous familial hypercholesterolemia $(\mathrm{FH})$ is a serious disorder causing twice normal low-density lipoprotein (LDL) cholesterol levels early in childhood and very early coronary disease in both men and women. Treatment with multiple medications together with diet can normalize cholesterol levels in many persons with $\mathrm{FH}$ and prevent or delay the development of coronary atherosclerosis. Previously published blood cholesterol criteria greatly under-diagnosed new cases of $\mathrm{FH}$ among members of known families with $\mathrm{FH}$ and over-diagnosed FH among participants of general population screening. Thus, there is a need for accurate and genetically validated criteria for the early diagnosis of heterozygous FH. In the course of investigations of coronary artery disease in Utah, we identified a family whose proband showed elevated plasma levels of LDL cholesterol. To carry out molecular genetic diagnosis of the disease, we screened DNA samples for mutations in all 18 exons and the exon-intron boundaries of the LDL receptor gene $(L D L R)$. Novel point mutations were identified in the proband: a C-to-T transversion at nucleotide position 631 , causing substitution of tyrosine for histidine at codon 190 in exon 4 of the $L D L R$ gene. The mutant allelespecific amplification method was used to examine $12 \mathrm{mem}$ bers of the family recruited for the diagnosis. This method helped to unequivocally diagnose 7 individuals as heterozygous for this particular $L D L R$ mutation, while excluding the remaining 5 individuals from carrier status with $\mathrm{FH}$.
\end{abstract}

Key words Hyperlipoproteinemia $\cdot$ Lipoproteins $\cdot$ LDL receptor $\cdot$ Familial hypercholesterolemia $\cdot$ Genetic diagnosis

P.N. Hopkins $(\bowtie) \cdot$ L.L. Wu $\cdot$ S.H. Stephenson $\cdot$ Y. Xin

R.R. Williams (posthumous)

Cardiovascular Genetics Research Clinic, University of Utah

Medical School, 410 Chipeta Way, Salt Lake City, UT 84108, USA

Tel. +1-801-581-3888 ext. 228; Fax +1-801-581-6862

e-mail:paul@ucvg.med.utah.edu

H. Katsumata $\cdot$ Y. Nobe $\cdot$ T. Nakajima $\cdot$ T. Hirayama $\cdot$ M. Emi Department of Molecular Biology, Institude of Gerontology, Nippon Medical School, Kawasaki, Japan

\section{Introduction}

Heterozygous familial hypercholesterolemia $(\mathrm{FH})$ is a dominant disorder attributable to a single gene defect on the short arm of chromosome 19 causing half of the low density lipoprotein (LDL) receptors on the surface of liver cells to function improperly, leading to decreased removal of LDL cholesterol (Goldstein et al. 1995). Plasma LDL cholesterol levels are approximately twice normal and usually can be detected by age 2 years. The combination of intensive dietary therapy and multiple prescription medication therapy offers an opportunity for substantially lowering or even normalizing blood cholesterol levels in many persons with this disorder. Studies using quantitative angiography have shown a statistically significant effect in preventing progression and even inducing regression of coronary atherosclerosis in FH patients treated aggressively with lipid-lowering medication (Kane et al. 1990; Thompson et al. 1995).

The $L D L R$ gene spans $45 \mathrm{~kb}$ of human genome and consists of 18 exons and 17 introns (Sudhof et al. 1985). No mutational "hot-spot" has been identified; in fact, specific mutations rarely recur among unrelated Caucasians (Hobbs et al. 1992; Russell et al. 1989). We describe here the identification of a novel mutation of the $L D L R$ gene in a hypercholesterolemic kindred in Utah. Our approach helped to unequivocally diagnose seven individuals as heterozygous for this particular $L D L R$ mutation while excluding the remaining five individuals from carrier status with $\mathrm{FH}$. In two of the affected individuals, identification would not have been possible using published LDL cholesterol criteria (Williams et al. 1993; Day et al. 1998).

\section{Patients}

Patients and lipoprotein measurement

The proband is a patient who has been followed by the Cardiovascular Genetics Research Clinic at the University 
of Utah. After 12-16h of fasting, blood samples were collected and prepared for each family member. Lipid and lipoprotein concentrations were measured by procedures described previously (Wu et al. 1989). In brief, plasma cholesterol and triglyceride concentrations were assayed enzymatically, and concentrations of high-density lipoprotein cholesterol (HDL-c) were determined by the $\mathrm{MgCl}_{2}$-dextran precipitation method. LDL was measured by ultracentrifugation after subtraction of HDL cholesterol from HDL + LDL cholesterol measured in the bottom fraction. These methods are routinely monitored and checked with both internal controls and standards supplied by the CDC Lipid Standardization Program.

Single-strand conformational polymorphism (SSCP) and sequencing analysis

SSCP was carried out as previously described (Orita et al. 1989). Each polymerase chain reaction (PCR) was initially carried out using $20 \mathrm{ng}$ of genomic DNA extracted from lymphocytes, in a $10 \mu \mathrm{l}$ solution containing $10 \mathrm{mM}$ Tris- $\mathrm{HCl}$ (pH 8.4), $50 \mathrm{mM} \mathrm{KCl}, 1.5 \mathrm{mM} \mathrm{MgCl}_{2}, 0.01 \%$ gelatin, $200 \mu \mathrm{M}$ each of dNTP, $2 \mu \mathrm{Ci}$ of [alpha $32 \mathrm{P}$ ]-dCTP $(3000 \mathrm{Ci} / \mathrm{mmol}$, $10 \mathrm{mCi} / \mathrm{ml}), 2.5 \mathrm{pmol}$ of each primer, and 0.25 units of Taq polymerase. PCR primers for amplification of each exon of the $L D L R$ gene and all exon-intron boundaries were previously described (Leitersdorf et al. 1990; Leren et al. 1993). Each of 35 PCR cycles consisted of 30 s at $94^{\circ} \mathrm{C}, 30$ s at $71^{\circ} \mathrm{C}$, and $30 \mathrm{~s}$ at $72^{\circ} \mathrm{C}$. Reaction mixtures were diluted with $50 \mu \mathrm{l}$ of $95 \%$ formamide dye and $20 \mathrm{mM}$ ethylenediaminetetraacetic acid (EDTA), incubated at $85^{\circ} \mathrm{C}$ for $5 \mathrm{~min}$, and applied $(2 \mu \mathrm{l} / \mathrm{lane})$ to $6 \%$ polyacrylamide gels containing $0.5 \times$ TBE $(90 \mathrm{mM}$ Tris-borate $/ 2 \mathrm{mM}$ EDTA) and $5 \%$ glycerol. Electrophoresis was performed both at room temperature and at $4{ }^{\circ} \mathrm{C}$. The gels were dried and autoradiographed with intensifying screens. When a variant band was revealed by SSCP analysis, the corresponding DNA fragment was sequenced directly on both strands to identify the nature of the mutation. The results were confirmed by two independent experiments.
Mutant allele-specific amplification (MASA) analysis

Genomic DNA was extracted from lymphocytes of 12 family members. PCR was carried out using $20 \mathrm{ng}$ of genomic DNA, $10 \mathrm{mM}$ of Tris- $\mathrm{HCl}(\mathrm{pH} 8.4), 50 \mathrm{mM}$ of $\mathrm{KCl}, 1.5 \mathrm{mM}$ of $\mathrm{MgCl}_{2}, 0.01 \%$ of gelatin, $200 \mu \mathrm{M}$ of $\mathrm{dNTP}_{\mathrm{S}}, 2.5 \mathrm{pmol}$ each of mismatched primer on one side and normal primer on the other side, and 0.25 units of Taq polymerase in a volume of $10 \mu \mathrm{l}$. For the "F-test" the sequence of the mismatched PCR primer was (5'-TCACAGCGCCAGCTGG-AGTA$\left.3^{\prime}\right)$. The sequence of the anti-sense primer was $\left(5^{\prime}\right.$ AGCTGTGGGC-CTGCGACAAC-3'). For the "R-test" the sequence of the mismatched PCR primer was (5'CCTAAGTGGCGAGTGCATCT- $3^{\prime}$ ). The sequence of the anti-sense primer was (5'-GCCCCCACCCTGCCCCGC-3'). Cycle conditions were $94^{\circ} \mathrm{C}$ for $3.5 \mathrm{~min}$, then 30 cycles of $94^{\circ} \mathrm{C}$ for $30 \mathrm{~s}, 71^{\circ} \mathrm{C}$ for $30 \mathrm{~s}$, and $72^{\circ} \mathrm{C}$ for $30 \mathrm{~s}$, with a final extension step of $3.5 \mathrm{~min}$ at $72^{\circ} \mathrm{C}$, in a Gene Amp PCR 9600 System (Perkin-Elmer Cetus, Foster, Ca USA). PCR products were electrophoresed in 3\% agarose gels and DNA visualized by ethidium-bromide staining.

\section{Results}

The pedigree structure of this family is shown in Fig. 1 . Affected status, as determined by the mutation analysis, is presented in Fig. 1a, with sex, age, and lipoprotein profile in Fig. 1b. Not shown are several apparently unaffected siblings in the generation II for whom blood was not available. None of the family members had a medical history of coronary artery disease or tendon xanthomas.

The proband was a Caucasian female patient (individual II-4, Fig. 1a) who is being followed by the Cardiovascular Genetics Research Clinic at the University of Utah. LDL cholesterol elevation in the proband's family appeared to follow a Mendelian, dominant mode of inheritance. At the time of blood draw, patient I-1 was being treated with simvastatin $20 \mathrm{mg}$ daily; and individual II- 1 with pravastatin $20 \mathrm{mg}$ daily. All other lipids in Fig. 1b are untreated values. Interestingly, it was not apparent from LDL cholesterol
Fig. 1. a Pedigree and mutational analysis of the proband (arrow) in the family. Square symbols, males; circles, females. b I.D. number, age, plasma levels of total cholesterol (T. Chol), triglyceride $(T G)$, shows high-density lipoprotein (HDL) cholesterol $(H D L c)$, and measured low-density lipoprotein (LDL) cholesterol $(L D L c)$ a

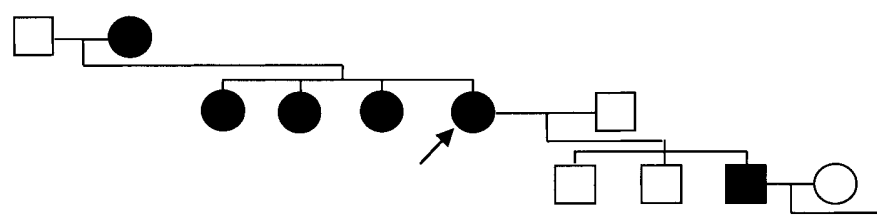

b

\begin{tabular}{lrrrrrrrrrrrr} 
ID & I-1 & II-1 & II-2 & II-3 & II-4 & III-1 & III-2 & III-3 & III-4 & IV-1 & IV-2 & IV-3 \\
age & 80 & 51 & 55 & 61 & 58 & 26 & 33 & 37 & 35 & 3 & \multicolumn{1}{c}{9} & 12 \\
T.Chol & 303 & 285 & 307 & 329 & 349 & 186 & 212 & 229 & 199 & 163 & 133 & 165 \\
TG & 90 & 174 & 109 & 146 & 163 & 172 & 326 & 405 & 117 & 141 & 108 & 117 \\
HDLc & 74 & 49 & 79 & 56 & 66 & 30 & 33 & 26 & 58 & 43 & 49 & 41 \\
LDLc & 211 & 199 & 215 & 235 & 277 & 123 & 89 & 110 & 134 & 92 & 77 & 98
\end{tabular}




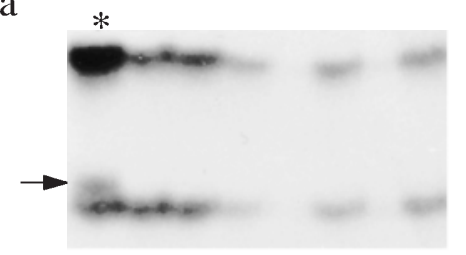

b

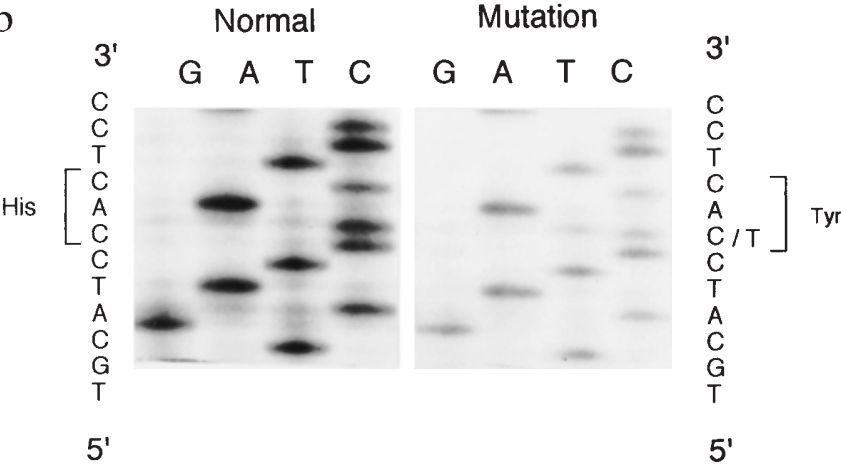

Fig. 2. a Single-strand conformational polymorphism (SSCP) analysis of exon 4 of the $L D L R$ gene in the proband. Arrow indicates the aberrant SSCP band observed in the proband's DNA. b Nucleotide sequencing and deduced amino acid sequences of the H190Y mutation, comparing normal allele and mutant H190Y allele

levels that individuals III-3 or IV-1 would have been affected. Plasma lipoprotein levels of the 58-year-old proband were: total cholesterol, $349 \mathrm{mg} / \mathrm{dl}$; triglyceride, $163 \mathrm{mg} / \mathrm{dl}$; HDL cholesterol, $66 \mathrm{mg} / \mathrm{dl}$; and LDL cholesterol, $277 \mathrm{mg} / \mathrm{dl}$.

Mutation screening of the $L D L R$ gene in the proband's genomic DNA identified an aberrant SSCP pattern in the PCR amplification product of exon 4 (Fig. 2a). Direct sequencing on both strands revealed heterozygosity for a C-to$\mathrm{T}$ transversion at nucleotide position 631 of the $L D L R$ cDNA. This transversion would substitute tyrosine for histidine at codon 190 (H190Y) (see Fig. 2b). H190Y was the only sequence variation detected in the entire coding with splicesite consensus sequences of the $L D L R$ gene of the proband.

The mutant allele-specific ampification (MASA) method was applied to examine 12 members of the family for the diagnosis. The MASA method was carried out on both strands of the mutant sequence; i.e., the F test (Fig. 3a) and the $\mathrm{R}$ test (Fig. 3b). Both tests detected mutant allelespecific amplification in the same 7 individuals of the family members concordantly. Thus, diagnosis as heterozygous for the H190Y LDLR mutation in the 7 individuals shown by black symbols in Fig. 1a was unequivocal, while the remaining 5 individuals were excluded from $\mathrm{FH}$ carrier status.

\section{Discussion}

Despite the impressive progress made in the understanding of the pathophysiology and treatment of $\mathrm{FH}$, it has been our anecdotal experience that many affected individuals are not

$\begin{array}{ccccccccccccc} & \text { II } & \text { II } & \text { II } & \text { II } & \text { III } & \text { III } & \text { I } & \text { III } & \text { IV } & \text { IV } & \text { III } & \text { IV } \\ \text { M } & 1 & 1 & 1 & \text { I } & \text { I } & \text { I } & \text { I } & \text { I } & 1 & \text { I } & \text { I } & \text { I } \\ \text { M } & 2 & 3 & 4 & 1 & 2 & 1 & 4 & 2 & 3 & 3 & 1\end{array}$

b

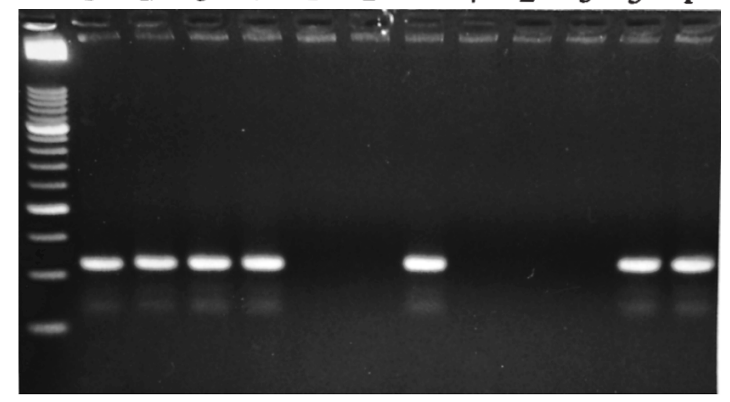

(R)

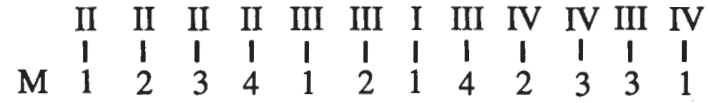

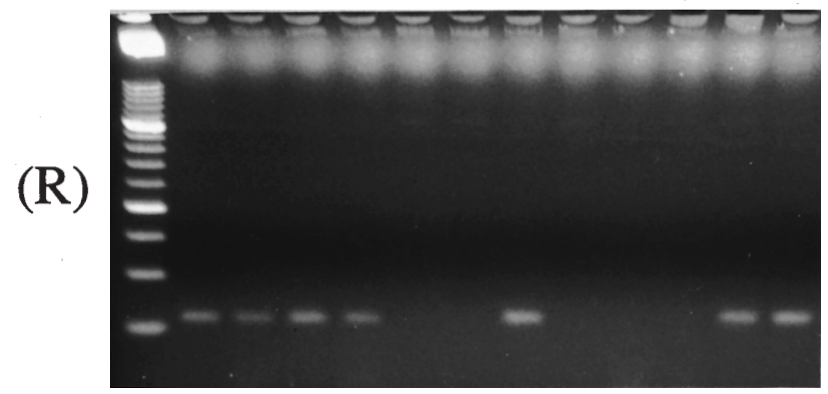

Fig. 3a, b. Mutant allele-specific amplification (MASA) analysis of H190Y mutation; a F-test, b R-test. The positive band at size $170 \mathrm{bp}$ in the F-test, and positive bands at size $110 \mathrm{bp}$ in the R-tests in specimens from affected individuals were visualized by ethidium-bromide staining of the polymerase chain reaction product run on $3 \%$ agarose gel

diagnosed or adequately treated for this disorder. Therefore, we initiated a project entitled "MedPed" (Make Early Diagnoses to Prevent Early Deaths in MEDical PEDigrees) to obtain objective information on the status of $\mathrm{FH}$ patients and to develop approaches for finding and helping these persons (Williams et al. 1993; Williams et al. 1996). The project emphasizes the power of family survey as well as DNA-based diagnostic approaches. From the start, the MedPed project objectives have been to evaluate and then develop solutions to the following critical issues of this lifethreatening disease: (1) to establish productive and costeffective methods for identifying persons and families with heterozygous FH, (2) to identify FH individuals who are not properly diagnosed and appropriately treated, using validated established diagnostic criteria, (3) to establish a process to assure initiation of correct treatment and compliance with this life-long treatment for every person with $\mathrm{FH}$, and (4) to apply, in a practical manner, knowledge obtained from research on this disorder.

It became clear from these initiatives that distinct clinical cholesterol criteria for the diagnosis of $\mathrm{FH}$ were needed. We therefore developed strategies for both the initial diagnosis of a previously undiagnosed FH family, and separate criteria for the subsequent diagnosis of other affected rela- 
tives (Williams et al. 1993; Day et al. 1998). Separate criteria for the initial diagnosis of a family versus the diagnosis of relatives within a well defined family are necessary, since in the general population the chance of inheriting hetetozygous FH is only 1 in 500 while first-degree relatives of a confirmed $\mathrm{FH}$ case have a $50 \%$ chance of having $\mathrm{FH}$. Nevertheless, these criteria depend entirely on LDL cholesterol levels and could miss carriers of $L D L R$ mutations who, for a variety of reasons, may have LDL cholesterol below the defined cut points.

Epi-genetic factors, as well as genetic factors, influence lipid levels in plasma. The nature of the $L D L R$ mutation also contributes to clinical variability among FH patients. It has been reported that individuals with mutations that only partially impair receptor function tend to have lower plasma LDL cholesterol levels than do individuals whose genes produce receptors devoid of any activity (Goldstein et al. 1995). In the present study, FH patients with the missense mutation H190Y tended to show markedly elevated levels of total cholesterol at middle-age and older (individuals II- 1 at age 51, II-2 at age 55, II-3 at age 61, and II-4 at age 58), while two younger individuals showed virtually normal LDL levels (individuals III-4 at age 37 and IV1 at age 3). Further studies will be needed to identify the reason(s) for the apparent lack of penetrance in these two individuals. In addition to the age-dependent penetrance, there is a remote possibility that hypercholesterolemia in this family is not linked to the $L D L R$ locus or is not due to the identified mutation. There is such potential for uncertainty at present, which may be solved by in-vitro LDL receptor assay or by linkage analysis in extended pedigrees in the future.

Functionally, $L D L R$ mutations are classified in five classes based on studies that involved fibroblasts derived from FH patients (Goldstein et al. 1995). Previously, several missense mutants occurring in the seven repeats of the ligand binding domain encoded by exons 2 through 6 have been functionally characterized (Hobbs et al. 1992). Since most result from encoded receptors that were blocked in transport between the endoplasmic reticulum and the Golgi apparatus (class 2; transport-defective alleles) (Hobbs et al. 1992; Russell et al. 1989), we postulate that the H190Y mutation reported here would cause the same class of deficiency on account of its location. However, other possibilities cannot be ruled out until proper functional tests are conducted for this particular mutation. Our study illustrates the feasibility of molecular genetic approaches for clinical diagnosis, thereby invoking appropriate early intervention in $\mathrm{FH}$ family members with predisposition to coronary heart disease.
Acknowledgments We thank Drs. Steven Hunt, Michael McGinty, Sawsan Ibrahim, Ed Lin, Stacey Larringa-Shum, and Loni Gardner for their contribution. This work was supported by an NHLBI grant R01 HL47561 from the NIH of USA; a grant-in-aid from the Ministry of Health and Welfare of Japan; and a grant-in-aid from the Ministry of Education, Science, Sports, and Culture of Japan.

\section{References}

Day INM, Hopkins PN (1998) Familial hypercholesterolemia. Report of a WHO Consultation. World Health Organization, Paris

Goldstein JL, Hobbs HH, Brown MS (1995) Familial hypercholesterolemia. In: Scriver CR, Beaudet AL, Sly WS, Valle D (eds) The metabolic and molecular bases of inherited disease. McGraw-Hill, New York, pp 1981-2030

Hobbs HH, Brown MS, Goldstein JL (1992) Molecular genetics of the LDL receptor gene in familial hypercholesterolemia. Hum Mutation 1:445-466

Kane JP, Malloy MJ, Ports TA, Phillips NR, Diehl JC, Havel RJ (1990) Regression of coronary atherosclerosis during treatment of familial hypercholesterolemia with combined drug regimens. JAMA 264:3007-3012

Leitersdorf E, Tobin EJ, Davignon J, Hobbs HH (1990) Common lowdensity lipoprotein receptor mutations in the French Canadian population. J Clin Invest 85:1014-1023

Leren TP, Solberg K, Rodningen OK, Ose L, Tonstad S, Berg K (1993) Evaluation of running conditions for SSCP analysis: application of SSCP for detection of point mutations in the LDL receptor gene. PCR Methods Appl 3:159-162

Orita M, Iwahana H, Kanazawa H, Hayashi K, Sekiya T (1989) Detection of polymorphisms of human DNA by gel electrophoresis as single-strand conformation polymorphisms. Proc Natl Acad Sci 86:2766-2770

Russell DW, Esser V, Hobbs HH (1989) Molecular basis of familial hypercholesterolemia. Arteriosclerosis 1989:1-8

Sudhof TC, Goldstein JL, Brown MS, Russell DW (1985) The LDL receptor gene: a mosaic of exons shared with different proteins. Science 228:815-822

Thompson GR, Maher VMG, Matthews S, Kitano Y, Neuwirth C, Shortt MB, Davies G, Rees A, Mir A, Prescott RJ, de Feyter P, Henderson A (1995) Familial Hypercholesterolaemia Regression Study: a randomised trial of low-density-lipoprotein apheresis. Lancet 345:811-816

Williams RR, Hunt SC, Schumacher MC, Hegele RA, Leppert MF, Ludwig EH, Hopkins PN (1993) Diagnosing heterozygous familial hypercholesterolemia using new practical criteria validated by molecular genetics. Am J Cardiol 72:171-176

Williams RR, Hamilton-Craig I, Costner GM, Hegele RA, Hayden MR, Pimstone SN, Faergeman O, Schuster H, E. S-T, Beisiegel U, Keller C, Czeizel AE, Leitersdorf E, Kastelein JC, Defesche JJP, Ose L, Leren TP, Seftel HC, Raal FJ, Marais AD, Eriksson M, Keller U, Miserez AR, Jeck T, Betterridge DJ, Humphries SE, Day INM, Kwiterovich PL, Lees RS, Stein E, Illingworth R, Kane J, Boulyjenkov V (1996) MED-PED: an integrated genetic strategy for preventing early deaths. In: Berg K, Boulyjenkov V, Christen Y (eds). Genetic approaches to noncommunicable diseases. SpringerVerlag, Heidelberg Berlin New York Tokyo, pp 35-45

Wu LL, Warnick GR, Wu JT, Williams RR, Lalouel JM (1989) A rapid micro-scale procedure for determination of the total lipid profile. Clin Chem 35:1486-1491 